\title{
A PARÓDIA EM MACHADO DE ASSIS E CAMILO CASTELO BRANCO: UMA BREVE ANÁLISE DE ME- MÓRIAS PÓSTUMAS DE BRÁS CUBAS E CORAÇÃO, CABEÇA E ESTÔMAGO
}

Greicy Bellin

(UFPR)

\section{RESUMO}

O objetivo do presente artigo é analisar algumas relações entre Machado de Assis e Camilo Castelo Branco no que concerne ao uso da paródia em Memórias póstumas de Brás Cubas e Coração, cabeça e estômago. A hipótese que se levanta é a de que Machado parodiou alguns aspectos do romance camiliano com a finalidade de emulá-lo, sinalizando uma busca por autoafirmação enquanto escritor em um cenário marcado por embates entre intelectuais brasileiros e portugueses. O embasamento teórico utilizado nesta análise parte do conceito de paródia formulado por Linda Hutcheon (1985), segundo a qual a paródia seria uma estratégia de fundo político, utilizada, no caso em tela, para reafirmar o lugar do escritor em contextos não-hegemônicos.

PALAVRAS-CHAVE: Paródia; identidade literária; herança portuguesa.

\section{INTRODUÇÃO}

Discorrer a respeito da presença estrangeira em Machado de Assis parece um lugar comum, dada a enorme quantidade de pesquisas e análises sobre este tema. As relações entre Machado e Camilo Castelo Branco, todavia, permanecem um tanto inexploradas, e, apesar de algumas tentativas consistentes terem sido feitas nos últimos anos, ainda cumpre destrinchar uma série de aspectos que nos ajudarão a compreender as maneiras pelas quais se estabelecem tais diálogos, considerando a inegável existência da herança portuguesa no contexto literário brasileiro do século XIX. 
O presente artigo objetiva realizar uma breve análise destas relações, lançando a hipótese de que Machado de Assis teria parodiado alguns aspectos de Coração, cabeça e estômago (1862) em Memórias póstumas de Brás Cubas (1881). Vale ressaltar que esta exposição traz os resultados parciais de uma pesquisa de pós-doutorado conduzida pela autora no Programa de Pós-Graduação em Letras da Universidade Federal do Paraná, sob a supervisão da prof. Dra. Patrícia da Silva Cardoso no âmbito do grupo de pesquisas Diálogos com a literatura portuguesa, cujo objetivo é investigar as interlocuções estabelecidas pela literatura portuguesa com outras literaturas, o que inclui, certamente, as relações entre Machado de Assis e os escritores portugueses.

O interesse por estes diálogos se observa na tese de doutorado de Marcelo Sandmann (2004), que reforça a escassez de "referências nominais de Machado a Camilo Castelo Branco, nome seminal da prosa portuguesa na segunda metade do séc. XIX” (SANDMANN, 2004, p. 439). Tal escassez também chamou a atenção de Paulo Franchetti (2011), que cita uma série de fatos que nos permitem estabelecer relações entre Machado e Camilo, entre eles a colaboração de ambos no periódico O Futuro, editado entre os anos de 1862 e 1863 por Faustino Xavier de Novais, cunhado de Machado e amigo muito próximo de Camilo. Soma-se a isso o fato de Machado ser filho de uma açoriana, juntamente com seu casamento com Carolina, uma portuguesa natural do Porto, além de variadas amizades com intelectuais portugueses que também faziam parte dos círculos intelectuais brasileiros da época. Há ainda estreita interlocução literária entre Machado e Almeida Garrett, Luís Vaz de Camões, Alexandre Herculano e Antônio Feliciano de Castilho, sendo que o primeiro é citado no prólogo de Memórias póstumas de Brás Cubas: "Toda essa gente viajou: Xavier de Maistre, à roda do quarto, Garrett na terra dele, Sterne na terra dos outros" (ASSIS, 2008, p. 623). O diálogo entre Machado e Eça se estabelece a partir da crítica a $O$ primo Basílio, publicada em 1878 e que teria sido, de acordo com João Cezar de Castro Rocha (2013), um dos elementos catalisadores da tão conhecida e comentada virada machadiana. Assim sendo, não é de se admirar a escassez de pesquisas sobre as relações entre Machado e Camilo, uma vez que os estudiosos tendem a se concentrar nos diálogos estabelecidos com Eça não pela simples preferência por um ou negligência em relação ao outro, mas pela importância assumida pela crítica ao romance queirosiano na compreensão da dinâmica do romance machadiano em sua fase madura. 
As relações entre Machado e os escritores portugueses assumem uma dimensão complexa se levarmos em consideração que, para Antonio Candido (1967), a literatura brasileira teria se formado a partir de um intenso "diálogo com Portugal", sendo caracterizada, ao mesmo tempo, pela constante busca por uma identidade nacional. Machado, enquanto figura chave da intelectualidade da época, se mostrou bastante preocupado em relação a esta problemática, como se pode perceber no famoso ensaio "Instinto de nacionalidade", em que propõe a ideia de "sentimento íntimo", segundo a qual o escritor deve ser "homem de seu tempo e de seu país, ainda que trate de assuntos remotos no tempo e no espaço" (ASSIS, 2008, p. 1205). Na visão de Paulo Franchetti (2011), as tensões entre o Brasil e a antiga metrópole iriam se tornar ainda mais acirradas em fins do século XIX por conta do advento da República, época na qual Machado atingiu sua maturidade literária, de forma que se torna realmente possível levar em conta o impacto destas complexas relações nos textos produzidos tanto por brasileiros quanto por portugueses. Nesse sentido, cumpre investigar o uso da paródia como estratégia da qual estes escritores irão lançar mão para questionar e problematizar os modelos literários oriundos dos países tidos como colonizadores, de forma a estabelecer relações que oscilam entre a adesão ao modelo estrangeiro e, ao mesmo tempo, o repúdio por este mesmo modelo.

Linda Hutcheon, em Teoria da paródia (1985), afirma que o recurso a elementos paródicos pode ser interpretado como uma forma de autorreflexividade, tendo em vista que estimula o desenvolvimento de percepções críticas relativas não só ao texto parodiado, mas também ao papel do leitor e do produtor nas relações de intertextualidade (HUTCHEON, 1985, p. 35). Na visão de Hutcheon, a paródia teria estreita correlação com a intenção autoral, transformando-se em um relevante elemento para investigação das possíveis posturas críticas sustentadas por um determinado escritor. Isso não significa, contudo, que ela seja sempre ridicularizadora, uma vez que o sentido etimológico do termo "paródia" comporta não só a ideia de contracanto, mas também a de canto paralelo ou ao lado do original. Assim sendo, a paródia pode vir a assumir uma dimensão respeitosa ou até mesmo, prestigiosa, o que, todavia, não a desveste de seu componente irônico, considerando o distanciamento que se opera quando um texto é parodiado.

Para Mikhail Bakhtin (1997), a paródia carnavaliza o discurso literário, evidenciando a presença de outras vozes e, portanto, de outros tex- 
tos em sua composição. O autor ainda afirma que "ao discurso parodístico é análogo o emprego irônico e todo o emprego ambíguo do discurso do outro, pois também nesses casos o discurso é empregado para lhe transmitir intenções que lhe são hostis" (BAHKTIN, 1997, p. 195). Linda Hutcheon, por sua vez, afirma que a paródia seria uma transcontextualização que iria desde uma citação ou alusão a uma verdadeira interpenetração entre discursos de ordem extratextual, com a finalidade tanto de prestigiar quanto de criticar e até mesmo, subverter o texto parodiado.

A fortuna crítica de Machado de Assis considera a paródia como elemento fundamental na obra do bruxo do Cosme Velho. Tal componente começou a ser sistematicamente investigado a partir do artigo de José Guilherme Merquior, intitulado "Gênero e estilo das Memórias póstumas", publicado em 1872, em que o autor afirma que as Memórias póstumas de Brás Cubas dialogariam com a tradição da sátira menipeia e com Laurence Sterne, Xavier de Maistre e Montaigne, apresentando ao leitor uma "novela filosófica" na qual predominaria a paródia e a "dessacralização carnavalesca" (MERQUIOR, 1972, p. 12). A tese de Merquior é levada adiante por Dirce Côrtes Riedel, segundo a qual "o texto de Machado é quase sempre baseado na paródia” (RIEDEL, 1979, p. 5), e por Enylton de Sá Rego (1989), segundo o qual a obra machadiana se caracteriza pela utilização sistemática da paródia a gêneros, estilos, temas e demais obras disponíveis na tradição literária e cultural, donde resulta um texto caracterizado pela mistura de gêneros, estilos e tons.

No que diz respeito a Camilo, José Edil de Lima Alves (1990) afirma que a recorrência de elementos paródicos em sua obra é "demasiado significativa para tratar-se de mera coincidência” (ALVES, 1990, p. 16). Na visão do autor, a análise do uso da paródia nos textos camilianos permite desvendar o senso crítico do escritor de São Miguel de Seide, revelando seu posicionamento face aos modelos em voga. Nesse sentido, Alves interpreta o uso da paródia como um "mecanismo integrador do modelo estrangeiro" na literatura portuguesa, e como "instrumento capaz de favorecer a execução de uma antropofagia cultural" (ALVES, 1990, p. 38). Tal procedimento estaria presente em Coração, cabeça e estômago, no qual Camilo realizava uma paródia dos romances franceses do século XIX, modelos estes ao qual precisava se submeter pelo fato de ser um escritor profissional, fator este que impactou sua obra de maneira significativa, conforme a célebre análise de Alexandre Cabral (1975). Há de se levar em consideração, sobre este aspecto, que a francofilia era também 
dado irrefutável do contexto literário brasileiro do século XIX, informação que encontra respaldo nos dados levantados por Márcia Abreu (2011) e Sandra Vasconcelos (2011). Dessa forma, torna-se possível aproximar Machado e Camilo no que diz respeito a uma sensibilidade forjada a partir do contato com a literatura estrangeira, no sentido de esmiuçar as estratégias utilizadas por estes escritores no estabelecimento de diálogos críticos com os modelos europeus em contextos não-hegemônicos como Brasil e Portugal no século XIX.

A existência das rivalidades entre intelectuais brasileiros e portugueses é objeto de controvérsias por parte de alguns escritores que discorreram a respeito das relações entre metrópole e ex-colônia, conforme sinaliza a passagem abaixo, da autoria de Manuel Pinheiro Chagas:

Se nos seios das classes menos ilustradas do povo brasileiros vivem tenazmente arraigados sentimentos de ódio contra os portugueses, que se manifestam por uma ou outra explosão deplorável, e que numa parte da imprensa encontram ecos selvagens, em compensação os homens esclarecidos do Brasil, não ocultam a sua viva simpatia por Portugal, assim como também os nossos homens mais ilustrados estendem sua mão amiga aos portugueses da América. Essa troca de simpatias é bem patente na literatura. Foi Alexandre Herculano o que primeiro saudou com entusiasmo o estro nascente e já brilhante de Gonçalves Dias as produções da imprensa portuguesa encontram sempre na crítica e no público do Brasil o mais ligeiro acolhimento. (CHAGAS, apud AUGUSTI, 2004, p. 2)

Apesar de Herculano realmente ter elogiado Gonçalves Dias, as relações entre as elites letradas portuguesa e brasileira nem sempre foram tão harmônicas quanto Pinheiro Chagas aponta em sua fala. Em fins da década de 60 do século XIX, começaram a surgir uma série de polêmicas literárias que sinalizam, de um lado, uma rivalidade brasileira em relação à ex-colônia e de outro, uma opinião depreciativa acerca do Brasil, percebido "como um país onde vivia gente ignorante, sem o mínimo lastro cultural" (AUGUSTI, 2004, p. 2). Camilo Castelo Branco, por exemplo, foi protagonista de uma polêmica surgida no ano de 1879, quando da publicação do Cancioneiro Alegre de poetas portugueses e brasileiros. Ao compilar a coletânea, o escritor teceu comentários nada elogiosos acerca das obras de Gonçalves Dias e Fagundes Varela, provocando reações negativas entre os intelectuais e leitores brasileiros, entre eles Arthur Barreiros, que teria ameaçado agredir Camilo caso ele viesse ao Brasil, 
ao que o escritor português respondeu com vários impropérios, também ameaçando seu interlocutor (AUGUSTI, 2004, p. 4).

De acordo com Paulo Franchetti, a acidez de Camilo em relação aos poetas brasileiros, caracterizada por comentários maldosos de fundo racista, teria feito com que Machado, ao escrever o romance de sua virada ficcional em 1881, ou seja, dois anos após a polêmica, transformasse o nome do escritor português em uma espécie de tabu, o que não significa que as interlocuções não estivessem presentes em sua própria obra. A ideia de uma suposta rivalidade entre Machado e Camilo, aliás, poderia ser vista como contraditória se pensarmos que o escritor brasileiro elogiou o português na seção "Revista Dramática", em 13 de abril de 1860, deixando entrever uma "ampla simpatia" ao criticar a peça $E S$ pinhos e Flores, drama camiliano representado nos palcos fluminenses também no ano de 1860 . No entanto, o elogio a Camilo foi feito muito antes da polêmica do Cancioneiro, o que não exclui a possibilidade de se pensar no estabelecimento de relações críticas e reflexivas por meio da paródia, principalmente se levarmos em consideração a tendência, tida como tipicamente machadiana, de lançar mão dos modelos literários para depois criticá-los. Marta de Senna se refere a esse jogo intertextual como "olhar oblíquo", a partir do qual o escritor se apropria do texto fonte para parodiá-lo e ao mesmo tempo, corroborar os temas que deseja desenvolver (SENNA, 1998, p. 13). João Cezar de Castro Rocha, em Machado de Assis: por uma poética da emulação (2013), analisa as relações entre Machado e Eça como um processo no qual o escritor brasileiro, "partindo da imitação de um modelo considerado autoridade num determinado gênero, busca-se emular esse modelo, produzindo uma diferença em relação a ele" (ROCHA, 2013, p. 12). Na visão do autor, a poética da emulação seria uma forma de responder literariamente a uma "situação concreta de grande desequilíbrio nas relações de poder cultural", relações estas que também se observariam, em certa medida, nos diálogos entre Machado e Camilo.

Sobre este aspecto, Lúcia Bastos Neves e Tânia Bessone Ferreira sublinham a existência de uma "guerra de pena" entre intelectuais brasileiros e portugueses por meio de jornais e folhetos em circulação no Rio de Janeiro oitocentista, guerra essa que evidencia a "alternância entre atração e repulsa em função das relações diplomáticas entre nações irmãs" (NEVES E FERREIRA, 2003, p. 107). Tais disputas eram intensificadas por questões econômicas e sociais relacionadas a problemas mi- 
gratórios, uma vez que o contingente de imigrantes portugueses em solo brasileiro gerava concorrência no então incipiente mercado de trabalho. No entanto, as tradições culturais portuguesas ainda encontravam-se fortemente enraizadas no Brasil, dando margem a sentimentos contraditórios de aproximação e ao mesmo tempo, rejeição em relação a Portugal. Como prova disso, as autoras citam a comemoração do tricentenário de Luís de Camões, amplamente celebrado pela imprensa e pelos intelectuais brasileiros em fins do século XIX, e que contou com a participação de Machado de Assis. O evento nos dá pistas concretas da permanência de relações marcadas por antagonismos, rivalidades e ao mesmo tempo, por identificações e simpatias que não passaram despercebidas a escritores da envergadura de Machado e Camilo, que sempre se mostraram atentos aos dilemas e travejamentos enfrentados pelas literaturas portuguesa e brasileira.

As ligações entre Brasil e Portugal também se observam na criação do Real Gabinete Português de Leitura, do qual Machado foi assíduo frequentador e cujo objetivo era difundir a cultura letrada na sociedade brasileira. Vanessa Gonçalves dos Santos destaca a fundação do Grêmio Literário Português, em Belém do Pará, como sintomática dos vínculos existentes entre as duas nações, bem como a presença avassaladora dos romances de Camilo na composição do acervo, que contava com dois exemplares de Coração, cabeça e estômago, indicando o sucesso usufruído pela obra do escritor em terras brasileiras (SANTOS, 2014, p. 72). Machado certamente estava consciente deste sucesso e, como romancista que também era, teria parodiado alguns aspectos do romance camiliano em Memórias póstumas de Brás Cubas, engajando seu texto na busca por sua própria identidade enquanto escritor colonizado, que precisava subverter e, ao mesmo tempo, questionar os padrões literários trazidos pelo colonizador.

\section{MEMÓRIAS PÓSTUMAS DE BRÁS CUBAS E CO- RAÇÃO, CABEÇA E ESTÔMAGO: A PARÓDIA EM AÇÃO}

Jacinto do Prado Coelho, no célebre Introdução ao estudo da novela camiliana, aponta semelhanças entre Machado e Camilo a partir da leitura de Coração, cabeça e estômago, afirmando que "valia a pena estudar as relações entre os dois escritores" (COELHO, 1983, p. 354). De fato é possível identificar, nas Memórias póstumas de Brás Cubas, uma série de 
elementos textuais que possibilitam e justificam uma análise comparativa com o romance de Camilo, elementos estes que nos dedicaremos a analisar nos próximos parágrafos.

Os diálogos com o leitor, bem como a tematização constante das expectativas de leitura, são recursos frequentes nos dois romances em tela. Tais recursos aparecem de forma bastante clara tanto no "Preâmbulo" de Coração, cabeça e estômago quanto na seção intitulada "Ao leitor" das Memórias póstumas, na qual o defunto autor Brás Cubas problematiza a função do prólogo na estrutura romanesca, almejando estabelecer um vínculo com os seus possíveis leitores: "Mas eu ainda espero angariar as simpatias da opinião, e o primeiro remédio é fugir a um prólogo explícito e longo. O melhor prólogo é o que contém menos coisas, ou o que as diz de um jeito obscuro e truncado" (ASSIS, 2008, p. 626). O mistério em relação ao método de composição das memórias aparece em um comentário feito na sequência: "evito contar o processo extraordinário que empreguei na composição destas Memórias, trabalhadas cá no outro mundo. Seria curioso, mas nimiamente extenso, e aliás desnecessário ao entendimento da obra" (ASSIS, 2008, p. 626). De forma semelhante, o editor do romance camiliano se dirige, no preâmbulo, a um leitor identificado como Faustino Xavier de Novais, que conforme já citado era cunhado de Machado de Assis, a fim de explicar-lhe a natureza da obra que tem em mãos:

Tenho debaixo dos olhos, mal enxutos de saudade, três volumes escritos da mão de Silvestre.

O primeiro, na lauda, que serve de capa, tem a seguinte inscrição em letras maiúsculas: CORAÇÃO.

O segundo, menos volumoso, diz: CABEÇA.

O título do terceiro, e maior volume, é: ESTÔMAGO.

Nenhum deles designa época: mas quem tiver, como eu, particular conhecimento do indivíduo, pode, sem grande erro, cronológico, datar os três manuscritos.

O Coração reina desde 1844 até 1854 . São aqueles dez anos em que nós vimos Silvestre fazer tolice brava.

Em 1855 notamos a transfiguração do nosso amigo, que durou até 1860, época em que tu já tinhas trocado o patrimônio da estima dos teus conterrâneos pelas lentilhas no Novo Mundo. Não viste, pois, a transição que o homem fez para o estômago, sepultura indigna das santas quimeras, que o entonteceram na mocidade, e consequência funesta da má direção que ele deu aos projetos, raciocínios e sistemas da cabeça. Podemos assinar tempo ao terceiro volume, desde 1860 até 
fim de 61, em que o autobiógrafo se desmanchou do que era para se arranjar doutro feitio. (CASTELO BRANCO, 2003, p. 7-8)

Observa-se a referência à ida de Novais para o Brasil em um comentário irônico do narrador, que, de forma bem-humorada, "acusa" o poeta de ter trocado a estima dos portugueses, percebida como um bem valioso, pelas "lentilhas do Novo Mundo". A paródia machadiana deste trecho transparece no mistério feito por Brás Cubas em relação à composição das Memórias, em uma atitude diametralmente oposta à do editor de Silvestre da Silva, que procura justificar, para o seu leitor, a divisão da obra em três partes. A suposta má qualidade da narrativa é também justificada em um trecho no qual se identifica a problemática situação do escritor profissional frente aos modelos literários estrangeiros em um contexto não-hegemônico:

Silvestre, como sabes, tinha muita lição de maus livros. Olha se lembras que os seus folhetins eram um viveiro de imoralidades vestidas, ou nuas, à francesa. Jornal em que ele escrevia morria ao fim do primeiro trimestre, depois de ter matado muitas ilusões. Quem hoje desembrulha um queijo flamengo, e lê no invólucro um folhetim de Silvestre, mal pensará que tem nas mãos o passaporte de muita gente para o inferno. (CASTELO BRANCO, 2003, p. 8)

Brás Cubas, por sua vez, admite ter adotado a "forma livre de um Sterne, ou de um Xavier de Maistre", tendo acrescentado "algumas rabugens de pessimismo" (ASSIS, 2008, p. 625). Estas são identificadas pelo próprio Machado de Assis como o diferencial do seu romance em relação aos modelos franceses e ingleses, levando em consideração que "é taça que pode ter lavores de igual escola, mas leva outro vinho" (ASSIS, 2008, p. 625). Tais dizeres nos permitem afirmar que Machado estava preocupado com a busca por uma identidade própria para sua obra, ainda que $o$ diálogo com os modelos estrangeiros estivesse presente em sua composição. E a busca por identidade literária certamente implica na paródia do discurso camiliano, ressignificado por uma ênfase maior no desdém em relação ao leitor e por uma radical problematização da forma romance, ainda que tal problematização também esteja presente no discurso do editor das memórias de Silvestre:

Os manuscritos de Silvestre careciam de ser adulterados para merecerem a qualificação de romance. É coisa que eu não faria, se pudesse. Acho aqui em páginas correntemente numeradas sucessos sem ligação 
nem contingência. Umas histórias em princípio, outras que começam pelo fim e outras que não têm fim nem princípio. Pode ser que eu, alguma vez, em notas, elucide as escuridades do texto, ou ajunte às histórias incompletas a catástrofe, que sucedeu em tempo que o meu amigo se retirara da sociedade, onde deixara a víscera dos afetos. (CASTELO BRANCO, 2003, p. 10)

As justificativas para as ações irrefletidas de Silvestre verificam-se em toda a narrativa, o que, juntamente com os diálogos estabelecidos com o leitor e com as constantes reflexões sobre as expectativas de leitura, confere a Coração, cabeça e estômago uma inegável carga metaficcional, como se próprio Camilo, personificado na figura do editor (e não seria um grande equívoco afirmar isso), estivesse refletindo sobre seu próprio fazer artístico em um cenário marcado pela importação de modelos literários estrangeiros e pela profissionalização do escritor. Os "sucessos sem ligação nem contingência" também aparecem nas Memórias póstumas, podendo ser interpretados como um esforço deliberado e consciente de problematização da forma romance em contextos considerados periféricos, tendo em vista as menções explícitas de Machado a Sterne e Xavier de Maistre, bem como a metáfora da taça com igual lavor que leva outro vinho.Camilo, de forma similar, retoma toda a tradição clássica portuguesa ao longo de sua narrativa com o objetivo de parodiá-la, apontando para o alto nível de reflexividade gerado, de acordo com Linda Hutcheon (1985), pelo uso sistemático da paródia.

Os narradores de ambos os romances são também peças importantes na construção dos efeitos paródicos, pois Silvestre, assim como Brás Cubas, também está morto quando sua história é narrada. A diferença fundamental em relação às Memórias póstumas é que tal narração se constrói por intermédio de cartas e pela presença do editor, que se constitui na principal instância paródica da narrativa. Nesse sentido, pode-se dizer que Machado não só parodia como emula o romance camiliano ao transformar o "defunto amigo" em "defunto autor", eliminando a presença do editor que, por sinal, é bastante irônico em relação ao protagonista: "A simpatia que o meu defunto amigo granjeou postumamente na república das letras e das tretas impõe-me o dever de empurrar portas adentro da imortalidade tudo o que lhe diz respeito" (CASTELO BRANCO, 2003, p. 3). Instaura-se, assim, uma atmosfera de narrativa além-tumular que será captada e, porque não dizer, radicalizada por Machado de Assis no romance considerado o marco divisório de sua produção literária. A pos- 
tura de Brás Cubas implica em uma radicalização da própria estrutura narrativa, expressa no primeiro parágrafo do primeiro capítulo do romance:

Algum tempo hesitei se devia abrir estas memórias pelo princípio ou pelo fim, isto é, se poria em primeiro lugar o meu nascimento ou a minha morte. Suposto o uso vulgar seja começar pelo nascimento, duas considerações me levaram a adotar diferente método: a primeira é que eu não sou propriamente um autor defunto, mas um defunto autor, para quem a campa foi outro berço; a segunda é que o escrito ficaria assim mais galante e mais novo. Moisés, que também contou a sua morte, não a pôs no introito, mas no cabo: a diferença radical entre este livro e o Pentateuco. (ASSIS, 2008, p. 626)

O narrador deixa bem claro que é um defunto autor e não um autor defunto, da mesma forma que o editor de Silvestre se refere ao protagonista como defunto amigo. Nesta passagem do "amigo" para o "autor", observa-se uma ficcionalização diferenciada da experiência além-tumular, que deixa de ser relato intermediado pelos vivos para se transformar em relato inverossímil, uma vez que narrado por alguém que já morreu. Trocando em miúdos, é como se Machado, ao ficcionalizar a experiência de morte e lançar mão de um defunto como instância narrativa, estivesse indo muito além do que fora Camilo com a representação de Silvestre, cuja vida permeada por exageros só veio à tona depois de sua morte por excesso de comida. Algo semelhante se observa em relação à vida de Brás Cubas, com a diferença de que suas aventuras são narradas por ele mesmo, evidenciando um irônico processo de autorrevelação que consiste, ao fim e ao cabo, em uma metáfora da situação do escritor em contextos não-hegemônicos, caracterizados pela subserviência aos modelos literários estrangeiros e ao mesmo tempo, pela necessidade constante de se buscar uma identidade própria, que só poderia ser construída com a "morte" do escritor. Cabe salientar, nesse sentido, que a imagem do estômago é também metafórica, ilustrando a situação do escritor profissional que se via submetido à deglutição, muitas vezes irrefletida, de modelos de grande apelo mercadológico, necessitando, ao mesmo tempo, de afirmação enquanto escritor original e dotado de real capacidade artística.

Indícios muito claros de paródia, já apontados por Marcelo Sandmann (2004) podem ser verificados na famosa dedicatória das Memórias póstumas, que retoma a dedicatória pensada por Silvestre da Silva para um romance que começara a escrever, intitulado Abismos do amor:"Ao anjo que conserva sua pureza na desgraça e que, antes de ser mártir, se 
chamou Mademoiselle Elise de laSallete, e hoje se chama apenas a Santa, consagra o autor esta urna de suas lágrimas" (CASTELO BRANCO, 2003, p. 40). Vale ressaltar que tanto a dedicatória de Brás Cubas ao "verme que roeu as frias carnes de meu cadáver" quanto aquela imaginada (mas não efetivamente publicada) pelo protagonista de Coração, cabeça e estômago apresentam a mesma disposição gráfica, o que nos permite afirmar que Machado estaria parodiando a narrativa camiliana com propósito emulativo, materializado na radicalização da ideia de destruição simbolizada pelo verme, ideia esta presente, em menor grau, na dedicatória de Silvestre. Esta é, aliás, ironizada pelo próprio protagonista com base na descoberta de que Elise de laSallete, modista francesa estabelecida em Lisboa e cortejada por seu amigo Cibrão Taveira, não possuía a conduta irrepreensível atribuída a ela em um primeiro momento. Nesse sentido, observa-se que Camilo lança mão do episódio da francesa para refletir a respeito do travejamento literário experimentado no contexto oitocentista português:

A francesa, que me escutava as maravilhas amorosas em vasconço, era uma esbelta moça que devia ter sido muito festejada no seu Paris, antes dos trinta anos, e viera naturalmente a reflorir estranhos climas, em país de tolos, como este nosso, tolos esquisitos que, até no amor, adoram o galicismo, ainda mesmo que, na boa linguagem francesa, ele já tenha caído em desuso por antiquado e de mau quilate. (CASTELO BRANCO, 2003, p. 37)

A existência de tal reflexão é reforçada pelo fato de que Silvestre ensina francês a Cibrão a fim de que ele possa cortejar a modista, em uma clara alegoria do esforço do escritor lusitano para se adequar aos modelos importados de fora. O dilema entre forma europeia e experiência local é evidente no seguinte comentário irônico de Silvestre, feito por ocasião do pedido de seu amigo:

Não me pareceu custoso fingir a língua de Vítor Hugo, sendo a semelhança julgada pela modista. Parece-me que Vítor Hugo não entenderia as minhas cartas escritas no seu idioma; quero, porém, acreditar que a francesa não acharia mais poesia nem mais correção raciniana no poeta das Orientais. (CASTELO BRANCO, 2003, p. 34)

A passagem revela não apenas o dilema da importação da experiência literária em contextos não-hegemônicos, mas a ideia, apontada por João Camilo dos Santos, de que o modelo literário europeu estava sendo mal compreendido e, talvez, mal imitado em Portugal por aqueles que, as- 
sim como Silvestre, tentavam imitar o comportamento dos "verdadeiros" escritores românticos, entre eles Victor Hugo (SANTOS, 1992, p. 18). Prova disso não os esforços do protagonista para assumir um ar fatal a fim de remediar o "infortúnio de ter saúde", o que seria, na visão de Santos, indicativo da inadequação portuguesa ao modelo estrangeiro. Dessa maneira, Camilo estaria, não de forma moralista mas de maneira lúcida e sarcástica, apontando para a busca de uma identidade literária própria e desvinculada do modelo literário europeu, busca esta que também caracterizava o contexto cultural brasileiro.

Machado de Assis certamente captou a mensagem camiliana e usou-a como parâmetro para a elaboração de uma dedicatória que parodia, em última instância, a ideia de decadência associada tanto à figura feminina de moral questionável, representada por Camilo, quanto à figura masculina cuja moral será desnudada e dissecada sem piedade pelo narrador além-tumular, que, no final das contas, realiza uma paródia de si mesmo. A autoparódia também se verifica ao longo de Coração, cabeça e estômago, nas constantes transformações de Silvestre da Silva, materializadas na divisão do romance nas partes identificadas no próprio título da obra. Isso não significa, entretanto, que a decadência associada à figura feminina não esteja presente no romance de Machado. É possível destacar vários momentos em que as personagens femininas, usualmente as mulheres que passaram pela vida do narrador, são descritas de forma a evidenciar a violenta desromantização e a destruição já expressas na dedicatória do romance e presentes, por exemplo, na figura de Eugênia, a "flor da moita":

O pior é que era coxa. Uns olhos tão lúcidos, uma boca tão fresca, uma compostura tão senhoril; e coxa! Esse contraste faria suspeitar que a natureza é às vezes um imenso escárnio. Por que bonita, se coxa? Porque coxa, se bonita? Tal era a pergunta que eu vinha fazendo a mim mesmo ao voltar para casa, de noite, sem atinar com a solução do enigma. (ASSIS, 2008, p. 666)

Brás encontrará a "Vênus manca" muitos anos depois, em um "cortiço distribuindo esmolas" (ASSIS, 2008, p. 757). A decrepitude também se observa na figura de Marcela, no capítulo em que Brás a encontra em uma loja na rua dos Ourives:

Não podia ter sido feia; ao contrário, via-se que fora bonita; mas a doença e uma velhice precoce destruíam-lhe a flor das graças. As bexigas tinham sido terríveis; os sinais, grandes e muitos, faziam saliências e encarnas, declives e aclives, e davam uma sensação de lixa grossa, 
enormemente grossa. Eram os olhos a menor parte do vulto, e aliás tinham uma expressão singular e repugnante, que mudou, entretanto, logo que eu comecei a falar. Quanto ao cabelo, estava tão ruço e quase tão poento como os portais da loja. (ASSIS, 2008, p. 670)

Alguns capítulos adiante, Brás, perturbado pelo encontro com Marcela, tem uma alucinação ao ver o rosto de Virgília, descrita no início do romance como uma "imponente ruína": "As bexigas tinham comido-lhe $o$ rosto; a pele, ainda na véspera tão fina, rosada e pura, aparecia-me agora amarela, estigmada pelo mesmo flagelo que devastara o rosto da espanhola." (ASSIS, 2008, p. 672). As imagens de decadência se repetem nas figuras de D. Plácida, Quincas Borba e Nhã-loló, cujo epitáfio pode ser também interpretado como um desdobramento da paródia à dedicatória de Silvestre à Elise de laSallete, considerando que a semelhança nas disposições gráficas de ambas (ASSIS, 2008, p. 738)

\author{
Aqui jaz \\ D. Eulália Damascena de Brito \\ Morta \\ Aos dezenove anos de idade \\ Orai por ela!
}

A desromantização da figura feminina, evidente em todas as passagens citadas acima, pode ser corroborada por frequentes comentários de cunho metaliterário, que apontam para a lucidez de ambos os escritores em relação a um contexto literário caracterizado não só pela importação do modelo estrangeiro mas também pelo progressivo abandono de fórmulas românticas associadas a tais modelos. A problematização machadiana de tais aspectos aparece na descrição que Brás Cubas faz de si mesmo no décimo-quarto capítulo das Memórias póstumas:

Ao cabo, era um lindo garção, lindo e audaz, que entrava na vida de botas e esporas, chicote na mão e sangue nas veias, cavalgando um corcel nervoso, rijo, veloz, como o corcel das antigas baladas, que o romantismo foi buscar ao castelo medieval, para dar com ele nas ruas do nosso século. O pior é que o estafaram a tal ponto, que foi preciso deitá-lo à margem, onde o realismo o veio achar, comido de lazeira e vermes, e, por compaixão, o transportou para seus livros. (ASSIS, 2008, p. 644)

A citação nos dá pistas de um modelo ultrapassado e, porque não dizer, usado pelos escritores por compaixão devido à sua decadência, ma- 
nifesta na ideia da devoração pelos vermes. Em Coração, cabeça e estômago, a crítica a aspectos defasados do movimento romântico aparece na paródia à poesia de Antonio Feliciano de Castilho, que havia sido colocada em prática por Silvestre para conquistar D. Paula de Albuquerque, outra mulher de índole questionável:

Ao terno cantor, que n'alma

Tem da amante o nome escrito,

Solitária amante envia

Saudades do periquito.

Ao meigo vate, que eu amo

Com amor casto e infinito,

Manda um doce e ardente beijo

O saudoso periquito.

$\mathrm{Na}$ rocha alpestre

Vaga Silvestre

Todo aflito;

$\mathrm{Na}$ grande testa

$\mathrm{O}$ vento intesta

Com rouco grito,

E ele a gemer

E o eco a dizer:

“Ó periquito!” (CASTELO BRANCO, 2003, p. 71-72)

A paródia camiliana ao estereótipo do romântico incurável foi certamente reconhecida por Machado, que teria se identificado com ela e radicalizado, a partir de tal identificação, seus processos de representação e narração literárias, caracterizados pela voz além-tumular de Brás Cubas e pela recorrente imagem da flor, usada pelo narrador para descrever a si próprio, Eugênia, Virgília, Quincas Borba e até mesmo sua hipocondria, caracterizada como "flor amarela e mórbida". Assim sendo, torna-se possível afirmar que Machado estaria parodiando o romance camiliano, sendo que tal paródia, ao contrário do que afirma Bakhtin (1997), não representa propriamente uma intenção hostil de um escritor para com o outro e sim, como quer Linda Hutcheon (1985), uma estratégia de fundo político, usada com o objetivo de provocar um distanciamento a partir do qual um dos autores, no caso Machado, desenvolve e amplia aspectos já trabalhados e problematizados pelo outro, Camilo. 
Com base em tudo o que foi exposto, pode-se afirmar que a exploração das possíveis relações entre Machado e Camilo tem por finalidade não só ampliar o escopo de investigação de obras consagradas dentro dos cânones das literaturas brasileira e portuguesa, mas também gerar novas possibilidades de entendimento acerca das relações entre Brasil e Portugal, fulcrais para a formação de identidades literárias próprias em contextos não-hegemônicos. Tal identidade teria sido construída por Machado de Assis a partir do uso de procedimentos paródicos que não visavam necessariamente a exaltação de si mesmo ou o rebaixamento de outros escritores, mas um diálogo crítico e produtivo com os modelos colonizadores, entre eles o lusitano, representado pela obra de Camilo Castelo Branco. É realmente possível que Machado, lançando mão de contumaz ironia, tenha elaborado, no romance de sua virada ficcional, uma resposta ao romance de Camilo com a finalidade de reafirmar sua própria identidade e, porque não dizer, seu lugar como escritor em um contexto marcado pela subserviência cultural e pela assimilação passiva de modelos estrangeiros.

\section{PARODY IN MACHADO DE ASSIS AND CAMILO CASTE- LO BRANCO: A BRIEF ANALYSIS OF MEMÓRIAS PÓS- TUMAS DE BRÁS CUBAS AND CORAÇÃO, CABEÇA E ESTÔMAGO}

\section{ABSTRACT}

This article aims at analysing the relationship between Machado de Assis and Camilo Castelo Branco, regarding the use of parody in $\mathrm{Me}$ mórias póstumas de Brás Cubas and Coração, cabeça e estômago. Our hypothesis is that Machado parodied some aspects of Camilo's novel in order to emulate it, pointing to a search for self-assurance as a writer in a literary context, characterized by the disputes between Brazilian and Portuguese intellectuals. The theoretical basis for this argumentation comes from the concept of parody as it was elaborated by Linda Hutcheon (1985), according to whom parody would be a political strategy, used, in the case we seek to analyze, to reaffirm the place of the writer in non-hegemonic contexts.

KEYWORDS: Parody; literary identity; Portuguese heritage. 


\section{REFERÊNCIAS}

ABREU, Márcia de Azevedo.(Coord.) A circulação transatlântica dos impressos: a globalização da cultura no século XIX. Campinas: UNICAMP. Biblioteca César Lattes, 25 ago. 2011. (Fundação de Amparo à Pesquisa do Estado de São Paulo: FAPESP). Projeto em andamento.

ALVES, José Edil de Lima. A paródia em novelas-folhetins camilianas. Lisboa: Instituto de Cultura e Língua Portuguesa, 1990.

ASSIS, Machado de.Obra completa. vols. 1 e 4. Rio de Janeiro: Nova Aguilar, 2008 .

AUGUSTI, Valéria. Polêmicas literárias e mercado editorial Brasil-Portugal na segunda metade do século XIX. I Seminário Brasileiro sobre Livro e História Editorial, Rio de Janeiro: Fundação Casa Rui Barbosa, p. 1-7, 2004.

BAKHTIN, Mikhail.Problemas da poética de Dostoiévski. Rio de Janeiro: Forense Universitária, 1997.

CABRAL, Alexandre. As polêmicas de Camilo Castelo Branco. Lisboa: Portugália, 1975.

CASTELO BRANCO, Camilo. Coração, cabeça e estômago. Organização e apresentação de Paulo Franchetti. São Paulo: Martins Fontes, 2003.

CAVALCANTI, Paulo. Eça, o agitador do Brasil. São Paulo: Companhia Editora Nacional, 1966.

COELHO, Jacinto do Prado. Introdução ao estudo da novela camiliana. Lisboa: Imprensa Nacional Casa da Moeda, 1983.

FRANCHETTI, Paulo. Machado e Camilo. In: ABRALIC, 2011. Curitiba: Anais... Universidade Federal do Paraná, 2011. Disponível em:http://www.abralic.org.br/ anais/cong2011/AnaisOnline/resumos/TC0622-1.pdf Acesso em:12/07/2016.

HUTCHEON, Linda. A theory of parody: the teachings of twentieth-century art forms. New York: Routledge, 1985.

MERQUIOR, José Guilherme. Gênero e estilo nas Memórias póstumas de Brás Cubas. Colóquio/Letras, Lisboa, 8, p. 12-20, 1972.

NEVES, Lúcia Bastos; FERREIRA, Tânia Bessoni. Brasil e Portugal: percepções e imagens ao longo do século XIX. In: MARTINS, Estevão Chaves de Rezende (org). Relações internacionais: visões do Brasil e da América Latina. Brasília: IBRI, 2003. p. 107-132.

REGO, Enylton de Sá. O calundu e a panaceia: Machado de Assis, a sátira menipeia e a tradição luciânica. Rio de Janeiro: Forense Universitária, 1989. 
RIEDEL, Dirce Cortes. A metáfora: o espelho de Machado de Assis. Rio de Janeiro: Francisco Alves, 1974.

ROCHA, João Cezar Castro. Machado de Assis: por uma poética da emulação. Rio de Janeiro: Civilização Brasileira, 2013.

SANDMANN, Marcelo. Aquém-além-mar: presenças portuguesas em Machado de Assis. Tese (Doutorado em Letras) Programa de Pós-Graduação em Teoria e História Literária, UNICAMP, Campinas, 2004.

SANTOS, João Camilo. Os malefícios da literatura, do amor e da civilização: ensaios sobre Camilo Castelo Branco. Lisboa: Fim de Século Edições, 1992.

SANTOS, Vanessa Suzane Gonçalves dos. "Ideias preliminares" sobre o romance: uma leitura dos prefácios camilianos. Dissertação (Mestrado em Letras). Programa de Pós-Graduação em Letras, UFPA, Belém, 2014.

SENNA, Marta de.O olhar oblíquo do bruxo: ensaios em torno de Machado de Assis. Rio de Janeiro: Nova Fronteira, 1998.

VASCONCELOS, Sandra Guardini. Romances sem fronteiras. In: ESCOLA SÃO PAUlO DE ESTUDOS AVANÇADOS, 2012, Campinas. Anais. Campinas, Unicamp, 2012.

Recebido em: 28 de julho de 2016

Aceito em: 22 de outubro de 2016 